\title{
A comprehensive study on correlation of gastropod diversity with some hydroenvironmental parameters of selected waterbodies of lower Damodar basin, West Bengal, India
}

\author{
Pratyush Ghosh* \\ Department of Zoology, Chandernagore College, Chandannagar, Hooghly-712136 \\ (West Bengal), India \\ A. K. Panigrahi \\ Ecotoxicology and Fisheries and Aquaculture Extension Laboratory, Department of \\ Zoology, University of Kalyani, Kalyani-741235 (West Bengal), India \\ *Corresponding author. E-mail: pratyushghosh60@gmail.com
}

\begin{abstract}
Gastropods, an important group of mollusc, inhabitants of sediment-rich bottom zone have evidentiary role in freshwater ecosystem. Their community structure has been influenced by the water and soil quality parameters. Under the scenario of intensive agricultural practice and fast urbanization waterbodies particularly the ponds of lower Damodar basin in Howrah district, West Bengal, India are badly affected by growing pollution load. In current study, three lentic waterbodies i.e Shiberjala pond, Nayachak Wetland and Dhasa Waterbody were chosen to assess the gastropod diversity. Selected physico-chemical parameters including Temperature, Dissolved Oxygen, pH, Free Carbon di oxide, Nitrate and Phosphate of all three waterbodies were determined also. Dhasa Waterbody containing 7 species, exhibited highest species richness. The density and species richness showed spatial variation among study sites. Bellamya bengalensis was the dominant species found at all study sites. Melanoides tuberculata in spite of their absence in Shiberjala pond, appeared to be the second most dominant species. Brotia $s p$ and Bithynia sp was the least abundant species. Gastropod species richness showed significant negative correlation with DO level $(r=-0.705, P<0.05)$. Nitrate level was significantly positively correlated $(r=0.474, P<0.05)$ with gastropod species richness and density. Phosphate level $(r=0.33)$ also positively correlated with gastropod richness.
\end{abstract}

Keywords: Aquatic, Gastropod, Species diversity, Correlation

\section{INTRODUCTION}

In terms of ecology and adaptive capability, Molluscs are one of the most successful invertebrate group. They are of cosmopolitan, their habitats ranging from deep marine trenches to the estuarine zones and freshwater to terrestrial habitats occupying a vast range. Bivalvia (Pelecypoda) and Gastropoda are the two freshwater molluscan group.

Physico-chemical profile of soil and water as well as the presence of detritus, exert an impact on the abundance of gastropods. Local environmental variables including temperature(Saddozai et al.,2013), productivity, types of sediment (Strzelec et al., 2014), pH and calcium(Briers,2003 and Smitha \& Mustak,2017), water chemistry and hydroperiod(Heino,2000 and Maltchick et al.,2010), macrophytic vegetation that provides food and shelter (Cruadrado,2015) provide explanation of gastropod assemblage structure in an aquatic habitat Gastropod, inhabitants of sediment rich bottom zone play crucial role in aquatic ecosys-

\section{Article Info}

DOI: 10.31018/jans.v10i4.1933 Received: October 20, 2018 Revised: November 15, 2018 Accepted: November 26, 2018

\section{How to Cite}

Ghosh, P. and Panigrahi, A.K. (2018). A comprehensive study on correlation of gastropod diversity with some hydroenvironmental parameters of selected waterbodies of lower Damodar basin, West Bengal, India. Journal of Applied and Natural Science, 10(4): 1259-1265 tem. Gastropods act as connector or link between nutrient resources and organic matter of the sediment with higher trophic strata (Wallace and Webster, 1996). They predictably and vibrantly react to human influences mainly caused by disposal of sewages, wastes etc. Gastropods are sedentary in nature with limited movement so they cannot evade the effect of pollution (Gaufin, 1973). Gastropods are considered as suitable diagnostic organism for assessing contamination (Hanaa et al., 2016).

Now a day, high intensity freshwater pollution is a matter of concern specifically in developing and poor countries (Bozzetti and Schulz, 2004). Most of the developing countries do not have infrastructure to alleviate the effects of water pollution (Hinrichsen et al.,1998). Poor income countries on average only treat $8 \%$ of domestic and industrial waste water, compared to $70 \%$ in developed countries (WWAP, 2017). It has been reported that about $75-80 \%$ of water pollution is caused by the domestic sewage (Kamble, 2014).

The wastes often contain variety of contaminants 
such as chlorinated hydrocarbons, petroleum based hydrocarbons and heavy metals, alkalis, various acids, dyes and many other chemicals which greatly alter the physico-chemical profile of water. These wastes are indiscriminately discharged directly and/or indirectly into aquatic systems. All the above mentioned chemicals are potentially harmful and may be fatally toxic to fish (Kumar, 1996; Aghor, 2007 and Patil, 2009) and other aquatic populations (Chakrabarty et al., 1959). $3.1 \%$ death occur every year due to unhygenic and poor quality of water(Pawari and Gowande,2015). Agricultural practices in river basins, flood plains introduce toxic pesticides, approximately 2 million tones/year with herbicide accounting for $47.5 \%$, insecticides $29 \%$ (De etal.2014) and remnants of chemical fertilizers to nearby waterbodies or canals or rivers. The surface water is the main sink of industries for waste disposal (Modak et al., 1990 and Lokhande et al., 2011), also receive agricultural runoff.

Thus, it is apparent that pollution load may interfere with fundamental functions of the aquatic habitats and may result in a loss of biodiversity from these systems (Singh et al., 1982). The detrimental impacts caused by pollution can be established by assessing the condition of aquatic ecosystems and various developmental strategies can be adopted for the up-gradation of water quality. Since the year 1900 , an estimated 64$71 \%$ of the natural wetland area worldwide has been lost due to anthropogenic activity (WWAP,2018) Conservation and protection of inland lentic water sources is a prior condition to meet the freshwater demands of future generation.Considering the grave condition of such waterbodies in lower Damodar basin in Howrah district,W.B, the present study was envisaged with objectives like determination of seasonal variations in the physico-chemical characteristics of water of pre-designated waterbodies, investigation of diversity and seasonal dynamics of Gastropod fauna of all the stations and assessment of the impact of pollution on gastropods.

\section{MATERIALS AND METHODS}

Study area: Three lentic freshwater bodies i.e Shiberjala pond, Nayachak Wetland and Dhasa (Figs. 1-3) located at lower Damodar basin in Howrah district of West Bengal were selected and the study was carried out for a period of six months i.e. from July 2017 to December 2017 to study the dynamics in the diversity of Gastropod fauna as follows:

Shiberjala pond (Water Body 1): Shiberjala pond (Fig. 1) in the district of Howrah, West Bengal, is a rural natural centennial impoundment and is located at a distance of about $3 \mathrm{Kms}$. from the Harisdadpur railway station (Howrah -Amta section, S. E. R) in Majukhetra village. It is a perenni- al, shallow, eutrophic water body with an area of about 247 square meters and depth ranging from 1.7 feet to 7 feet during the rainy season. There are 4 irregularly circular interconnected ponds with surface runoff, rain and wastewater from nearby rural households as the main source of water. The people mainly use the pond for bathing, washing clothes and bathing of the cattle. It is also for used fish culture. The water of the pond is turbid opaque and redish green in colour. The surface of the pond remains covered with a thick blanket of Lemna, Pistia species during most of the year except during rainy season Eichornia occasionally present. Margins of the pond bear Colocassia, Ipomoyea, Camelina etc. Run-off containing domestic waste, sewage and detergents, silt and decomposed organic matter enrich the pond with nutrients that supports the growth of aquatic macrophytes.

Nayachak wetland (Water Body 2): Nayachak wetland (Fig. 2 ) is located on riverine flood plains in Panchla block of Howrah district.It can be categorized as Marshes.This area is dominated by reeds,grasses and sedges. Phragmites, Typha, Scirpus, Carex, Juncus occur in the area. The whole area is flanked by presence of perennial waterbody locally known as beels. This low lying marshy land is used for agricultural purpose. Several small scale industries are set up at the southeastern corner of the aquatic habitat. Agricultural runoff and industrial effluent directly get stored in that marshyland. River kana Damodar or Kaushiki flows along the northern side of the marshy land.

Dhasa waterbody (Waterbody 3): Dhasa waterbody (Fig. 3) is a countryside natural centennial impoundment located in Jagatballavpur block of Howrah District, WestBengal. It is a perennial, eutrophic water body with an area of about 1050 square meters and depth ranging from 2.5 feet to 7.8 feet .The pond is more or less oval with surface runoff from adjacent agricultural fields, rain. The people mainly use the pond for irrigation, bathing, washing clothes and bathing of the cattle. The water of the pond is turbid and dull green in colour. The surface of the pond is occasionally covered by Lemna.

Physico-chemical analysis of water: For the physico-chemical analysis, monthly collections of the water samples were made from each of the waterbody between 7 am to10am. Estimation of various physic-chemical parameters like water temperature, atmospheric temperature, $\mathrm{pH}, \mathrm{DO}$, $\mathrm{FCO}_{2}$, Nitrate and Phosphate level were done on the spot and laboratory. Physico- chemical analysis of above mentioned parameters of the water samples collected from different study sites were done following standard methods (Chattopadhyay, 1998). Temperature was recorded by using a mercury bulb thermometer. Water temperature was recorded by placing the bulb of the thermometer 
Ghosh, P. and Panigrahi, A.K. / J. Appl. \& Nat. Sci. 10 (4): 1259-1265 (2018)
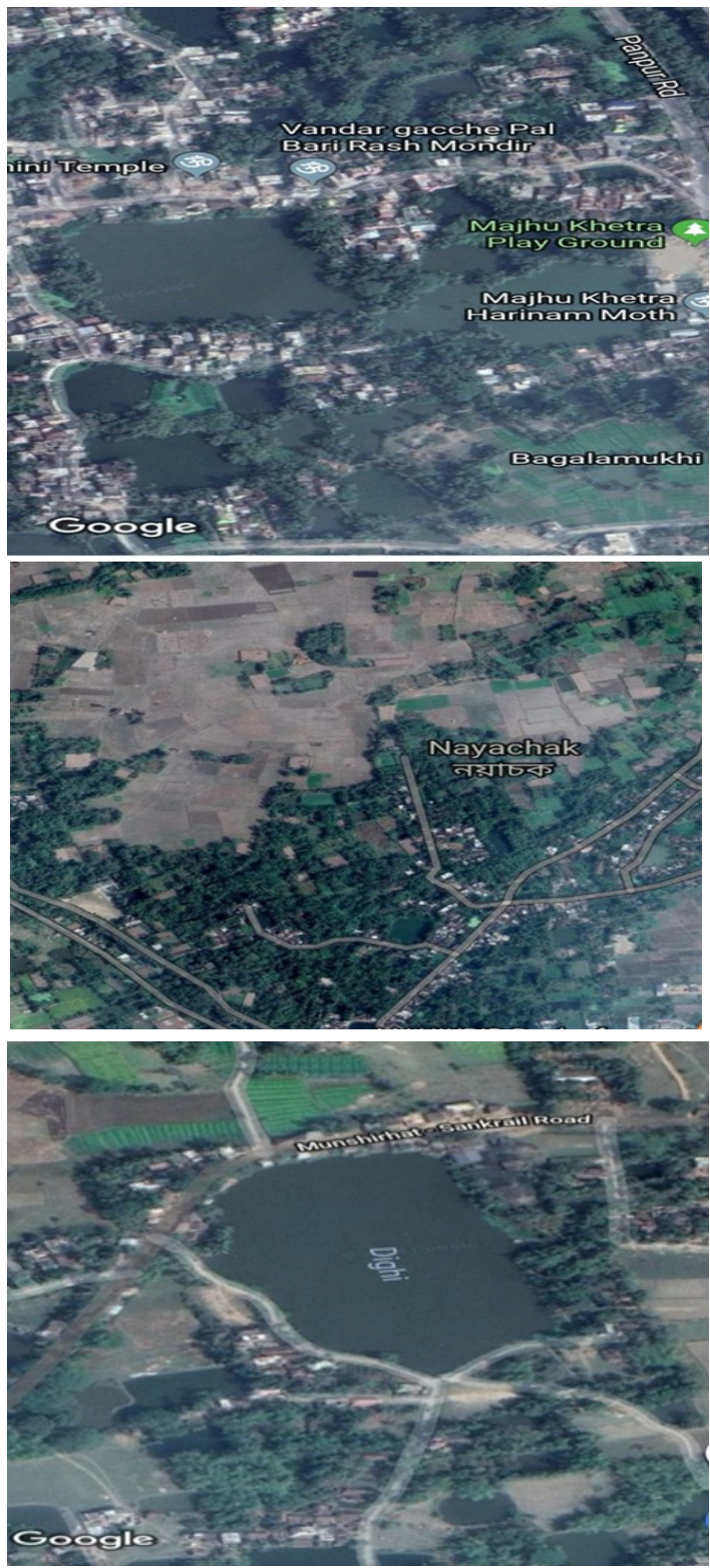

Figs. 1 to 3. Showing different lentic bodies of lower Damodar basin in Howrah district of West Bengal. 1. Shiberjala (Majhukhetra), 2: Nayachak wetland, 3. Dhasa waterbody.

four to five inches below the surface of the water for about 2 minutes at each station. $\mathrm{pH}$ of the water was determined by using a portable $\mathrm{pH}$ meter (Hanna, model) at the study site. Dissolved Oxygen of the water was determined by Sodium azide modification of Winkler's method (A.P.H.A., 2012). Here water samples were collected at respective sites. Manganous sulphate and alkaline iodide reagents $1 \mathrm{ml}$ each added in each bottle immediately. $\mathrm{FCO}_{2}$ was estimated by titrimetric method used phenolpthalin as an indicator. Phosphate concentration was determined spectrophotometrically $(690 \mathrm{~nm})$ by stannous chloride method using phenolphthalein indicator, molybdate reagent and stannous chloride reagent. The concentration of nitrate was also determined spectophotometrically $(410 \mathrm{~nm})$ using phenol disulphonic acid reagent (Chattopadhyay,1998).

Collection, qualitative and quantitative analysis of gastropods: For collecting gastropods the bottom soil samples were collected using an Ekman dredge having an area of $232 \mathrm{~cm}^{2}$. The soil samples collected were sieved immediately using no. 40 mesh size sieve (256 mesh per $\mathrm{cm}^{2}$ ). The organisms retained were segregated and their abundance was calculated as number per square meter following Jhingran (1982).

Preserved samples of gastropods were identified following Ward \& Whipple (1959), Tonapi (1980), Adoni (1985) and Pennak (1978). In order to identify the observed Gastropods up to species level the sampled organisms were carried to ZSI Kolkata.

The number Gastropod fauna was calculated by the formula:

$\mathrm{N}=\mathrm{O} / \mathrm{A} . \mathrm{S} \times 10,000$ Welch (1952) $\ldots . . . .$. Eq. 1

Where,

$\mathrm{N}=$ no. Gastropod organisms $/ \mathrm{m}^{2}$

$\mathrm{O}=$ no. of organisms counted

$A=$ area of metallic samples in square meter

$\mathrm{S}=$ no. of samples taken at each stations

Statistical analysis of data: The data were analyzed statistically for mean, standard deviation (S.D.), standard error (S.E.), the coefficient of variance (C.V.) and correlation with the help of Computerized Statistical Package for Social Sciences (SPSS Ver. 18) and paleontological Statistics software package for education and data analysis

\section{[PAST(3)]}

Correlation matrix: The correlation matrix was used because it standardizes the data and minimized variation caused by different scales of the environmental variables.

\section{RESULTS AND DISCUSSION}

The water quality parameters did not exhibit much difference among study sites (Fig 5). Though DO level showed little variation, as in Dhasa Waterbody DO level in September was recorded as low as $0.5 \mathrm{mg} / \mathrm{l}$ while highest DO level was evident in Shiberjala during December 2017 (5.9 mg/l)(Fig. 4).DO of Nayachak wetland and Dhasa waterbody never reached the level of $5 \mathrm{mg} / \mathrm{l}$ during the whole study period. $\mathrm{pH}$ was alkaline in Shiberjala pond and Nayachak wetland throughout the study period (Fig. 6). Dhasa Waterbody had a slightly acidic $\mathrm{pH}$. Mean $\mathrm{pH}$ of Dhasa Waterbody was $6.37 \pm 0.24$. The level of free Carbon dioxide of Shiberjala pond was low throughout the study period. Nitrate and phosphate level were seen considerably high at Dhasa waterbody. The mean value of phosphate and nitrate were $1.42 \mathrm{mg} / \mathrm{l}$ and 
Table 1. Pearson's Correlation Coefficients Matrix for gastropod species richness and water Quality parameters.

\begin{tabular}{|c|c|c|c|c|c|c|c|c|}
\hline \multicolumn{9}{|c|}{ Correlation matrix } \\
\hline & & DO & Temperature & FreeCO $\mathrm{CO}_{2}$ & $\mathbf{P}^{\mathrm{H}}$ & Phosphate & Nitrate & Richness \\
\hline \multirow[t]{3}{*}{$\overline{\mathrm{DO}}$} & Pearson Correlation & 1 & -.542 & .066 & .662 & $-.575^{*}$ & $-.759 "$ & $-.705^{\mathrm{m}}$ \\
\hline & Sig. (2-tailed) & & .020 & .793 & .003 & .013 & .000 & .001 \\
\hline & $\mathrm{N}$ & 18 & 18 & 18 & 18 & 18 & 18 & 18 \\
\hline \multirow[t]{3}{*}{ Temperature } & Pearson Correlation & $-.542^{*}$ & 1 & -.316 & .103 & .072 & .300 & $.664^{\star *}$ \\
\hline & Sig. (2-tailed) & .020 & & .201 & .686 & .776 & .227 & .003 \\
\hline & $\mathrm{N}$ & 18 & 18 & 18 & 18 & 18 & 18 & 18 \\
\hline \multirow[t]{3}{*}{ Free $\mathrm{CO}_{2}$} & Pearson Correlation & .066 & -.316 & 1 & -.044 & .046 & -.123 & -.093 \\
\hline & Sig. (2-tailed) & .793 & .201 & & .863 & .857 & .627 & .713 \\
\hline & $\mathrm{N}$ & 18 & 18 & 18 & 18 & 18 & 18 & 18 \\
\hline \multirow[t]{3}{*}{$\mathrm{P}^{\mathrm{H}}$} & Pearson Correlation & $.662^{* *}$ & .103 & -.044 & 1 & $-.603^{\star *}$ & $-.782^{\star \star}$ & -.224 \\
\hline & Sig. (2-tailed) & .003 & .686 & .863 & & .008 & .000 & .372 \\
\hline & $\mathrm{N}$ & 18 & 18 & 18 & 18 & 18 & 18 & 18 \\
\hline \multirow[t]{3}{*}{ Phosphate } & Pearson Correlation & $-.575^{*}$ & .072 & .046 & $-.603^{* *}$ & 1 & $.529^{*}$ & .330 \\
\hline & Sig. (2-tailed) & .013 & .776 & .857 & .008 & & .024 & .181 \\
\hline & $\mathrm{N}$ & 18 & 18 & 18 & 18 & 18 & 18 & 18 \\
\hline \multirow[t]{3}{*}{ Nitrate } & Pearson Correlation & $-.759^{* *}$ & .300 & -.123 & $-.782^{* \star}$ & $.529^{*}$ & 1 & $.474^{*}$ \\
\hline & Sig. (2-tailed) & .000 & .227 & .627 & .000 & .024 & & .047 \\
\hline & $\mathrm{N}$ & 18 & 18 & 18 & 18 & 18 & 18 & 18 \\
\hline \multirow[t]{3}{*}{ Richness } & Pearson Correlation & $-.705^{\star *}$ & $.664^{* *}$ & -.093 & -.224 & .330 & $.474^{*}$ & 1 \\
\hline & Sig. (2-tailed) & .001 & .003 & .713 & .372 & .181 & .047 & \\
\hline & $\mathrm{N}$ & 18 & 18 & 18 & 18 & 18 & 18 & 18 \\
\hline
\end{tabular}

${ }^{*}$. Correlation is significant at the 0.05 level (2-tailed), ${ }^{* *}$. Correlation is significant at the 0.01 level (2-tailed).

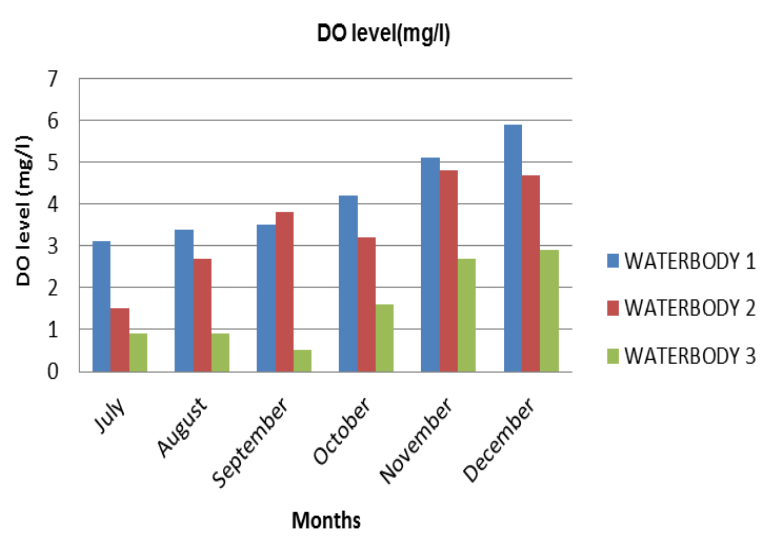

Fig.4. Variation in DO level in all three waterbodies during the study period.

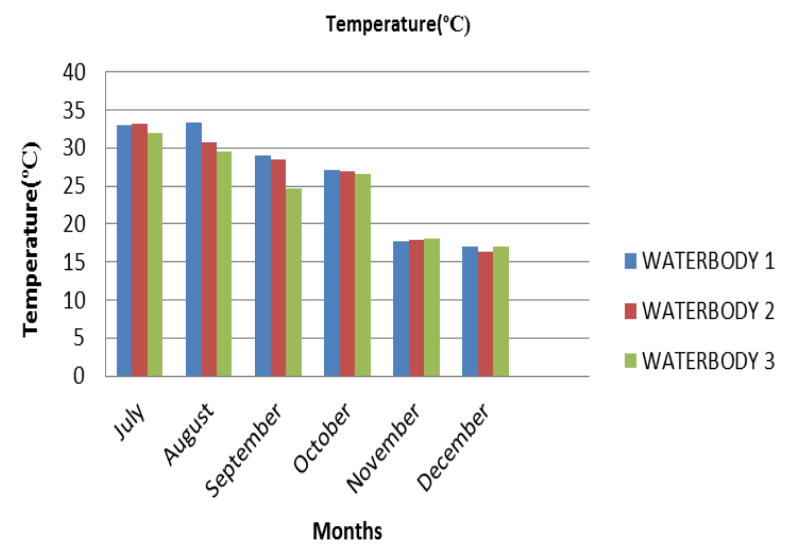

Fig. 5. Variation in temperature in all three waterbodies during the study period.

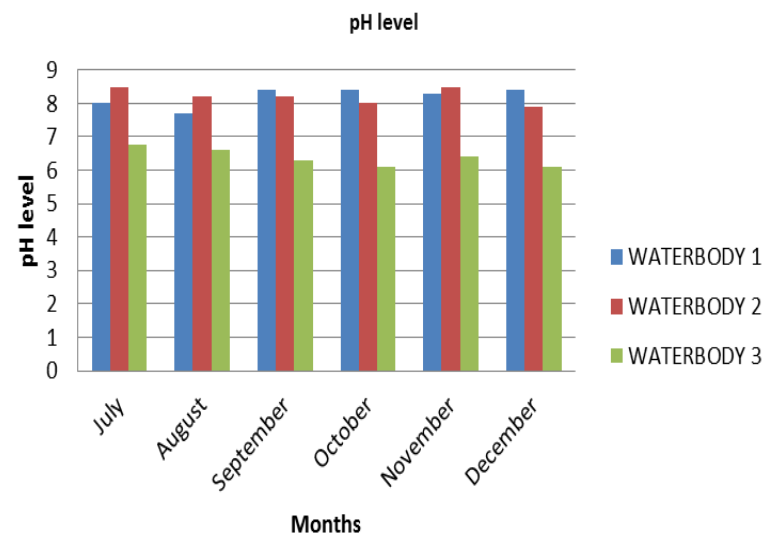

Fig. 6. Variation in $\mathrm{pH}$ level in all three waterbodies during the study period.

$6.76 \mathrm{mg} / \mathrm{l}$ respectively. Low phosphate level was seen at Shiberjala pond. Mean nitrate level of Shiberjala pond $\left(3.30 \mathrm{mg} / \mathrm{l}^{-1}\right)$ was greater than $\mathrm{Na}$ yachak (3.05 mg/l).

Total 8 Gastropod species were recorded belonging to 7 genera and 5 families. Dhasa Waterbody exhibited highest species richness. It contained 7 gastropod species. The density and species richness showed spatial variation among study sites. Bellamya bengalensis was redundantly found at all study sites. Melanoides tuberculata in spite of their absence in Shiberjala appeared to be the second most dominant species. In Shiberjala or waterbody 1, total 4 species were recorded. In Shiberjala pond, Bellamya bengalensis was the dominant group with relative abundance of $46.7 \%$, 


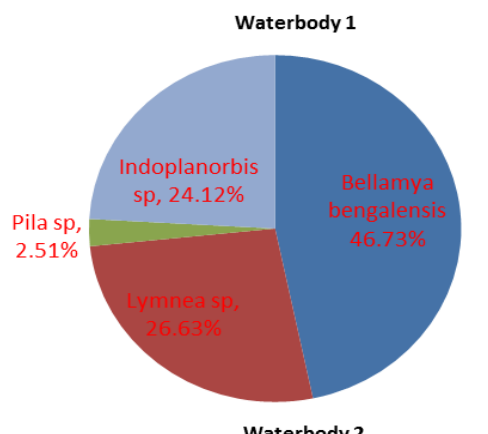

- Bellamya bengalensis

- Lymnea sp

- Pila sp

Bithynia $s p$

- Theara scabra

- Melanoides tuberculata

- Indoplanorbis $s p$

Brotia sp

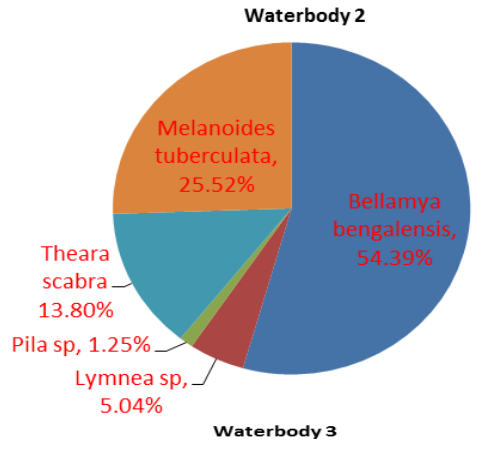

- Bellamya bengalensis

- Lymnea sp

- Pila $s p$

- Bithynia sp

Theara scabra

- Melanoides tuberculata

Indoplanorbis $s p$

- Brotia sp

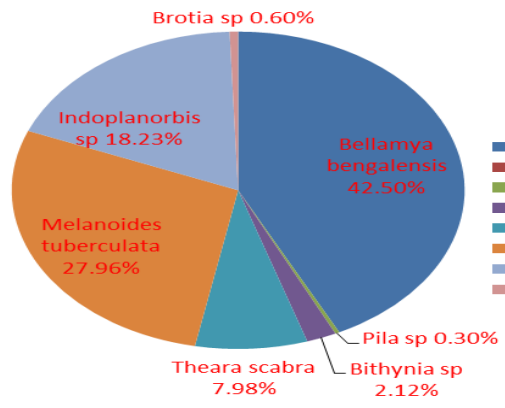

Fig. 7. Relative abundance of gastropod species.

while Pila sp. (2.51\%) was least abundant.Relative abundance of Indoplanorbis $s p$ and Lymnea $s p$ in Shiberjala were $24.12 \%$ and $26.63 \%$ respectively (Fig 7 ). In Nayachak waterbody or waterbody 2, again Bellamya bengalensis $(54.39 \%)$ was the most abundant group followed by M.tuberculata (25.52\%), Theara scabra $(13.80 \%)$, Lymnea sp. (5.04\%) and Pila sp. $(1.25 \%)$. Same dominance hierarchy was also evident in Dhasa waterbody or waterbody 3. In Dhasa waterbody relative abundance of Bellamya bengalensis and Melanoides tuberculata were $42.5 \%$ and $27.96 \%$ respectively.Pila sp $(0.30 \%)$ was the least abundant species of Dhasa waterbody.Brotia $s p$ and Bithynia $s p$. were observed only in Dhasa waterbody though their relative abundance is low $0.60 \%$ and $2.12 \%$ respectively (Fig. 7). In July the most (6) no of species were recorded in Dhasa waterbody.Gastropod population size fluctuated markedly, Gastropod population density (no of organisms $/ \mathrm{m}^{2}$ ) was higher during July and August and lowest during December. The fluctuations of physicochemical properties of the waterbody greatly affect Gastropod species richness and abundance. Ecology of aquatic habitats is greatly influenced by temperature (Huet,1986) by controlling the ecological characteristics of organisms as well as solubility of different gases and salts in water.Temperature recorded during the study period ranging from $16.4^{\circ} \mathrm{C}$ (in Waterbody 2,December2017) to $33.4^{\circ} \mathrm{C}$ (in Waterbody 1,August2017). Aziz et al. (1996) reported $20^{\circ} \mathrm{C}-35^{\circ} \mathrm{C}$ is conducive for growth and multiplication of gastropods. From the above observations it can be concluded that during the study period, temperatures of the studied waterbodies were conducive for gastropod's growth and reproduction. In the present study, Gastropods species richness showed significant positive correlation with temperature $(r=0.664, P<0.05)$ as shown in Table 1. Dutta and Malhotra (1986), Garg et al. (2009) and Palanisamy et al. (2012) also recorded a positive correlation between gastropods and temperature. During the present study, temperature of all three water bodies varies little (Fig 2). $\mathrm{pH}$ of the study sites ranged from 6.18.5 , thus is slightly acidic to mildly alkaline. A very weak insignificant negative correlation between Gastropods and $\mathrm{pH}$ was obtained in the current study (Table 1). Such results of the study are in agreement with the work of Garg et al. (2009). Extreme high or low $\mathrm{pH}$ is resulting in mortality of the aquatic organisms. Solubility and toxicity of many heavy metals in water is severely influenced by $\mathrm{pH}$. It makes them more mobile and that enhances their rate of absorption by aquatic organisms. (Selvanayagam and Abril, 2016).In the current study, the Gastropod richness found to be negatively correlated( $r=-.093)$ with the Free Carbon di oxide level (Table 1). Similar relationship also recorded by Sharma et.al. (2013).DO affects the solubility and availability of different nutrients and productivity of any aquatic ecosystems (Wetzel,1983). Gastropod species richness showed significant inverse correlation with DO level $(r=-0.705, P<0.05)$ as shown in Table 1 . This correlation finds supports from the work of Garg et al. (2009).Chaetum (1934) and Sharma (1986) also reported that some molluscan species can survive severe hypoxic conditions. Nitrate level was significantly positively correlated $(r=0.474$, $\mathrm{P}<0.05)$ with gastropod species richness and density (Table 1). Work of Roy et. al. (2014) has supported such correlation between two. High amount of phosphate in any waterbody is associated with eutrophication but at the same time it is one of the limiting factors for growth of aquatic organisms. In the present work, Phosphate level was also positively correlated $(r=0.33)$ with gastropod richness as shown in Table 1. Moderate positive correlation between Gastropod richness and Phosphate level also reported by Smitha and Mustak MS(2017). Infiltration of waste water from various point and nonpoint sources including domestic industrial, 
agricultural runoff is responsible for phosphate addition in any waterbody (Seyoum, 2007). Increased nitrate and phosphate level augment growth of algal flora. Some gastropod species feed on algal flora. So, positive correlation of nitrate and phosphate level with gastropod species richness can be explained by alimentation relationship According to Strzelec and Krolczyk (2004) many species of gastropod are tolerant to most physicochemical parameters and their occurrence is influenced by the quality of bottom sediments and abundance of vegetation.

\section{REFERENCES}

1. APHA (2012).Standard Methods for the examination of waste and waste water. $22^{\text {nd }}$ edition, American Public Health Association, Washington, D. C.

2. Adoni, A.D. (1985). Workbook on Limnology. Pratibha Publishers, C-10 GourNagar, Sagar, India.

3. Aghor, A. (2007). Chemicals make Thane creek the worst polluted water body. Dly.DNA, 14(7): 7-14

4. Aziz, M.A, and Raut, S.K. (1996). Thermal effect on the life- cycle parameters of medically important freshwater snail species Lymnea(radix) luteola Lamarck. Mem Inst Oswaldo Cruz, Rio de Jenerio, 91 (1):119-127

5. Bozzetti, M. andSchulz, U.H. (2004).An index of biotic integrity based on fish assemblages for subtropical streams in southern Brazil. Hydrobiologia, 529:133-144.

6. Briers, R.A, (2003). Range size and environmental calcium requirements of British fresh water gastropods. Global Ecology and Biogeography, 12(1)47-51. https://doi.org/10.1046/j.1466-822X.2003.00316.x

7. Chakrabarty, R.D., Roy, P., and Singh, S.B. (1959). A quantitative study of theplankton and physicochemical conditions of river Jamuna at Allahabad in 1954-1955. Indian J. Fisheries, 6(1): 186-203.

8. Chaetum,E.P.(1934). Limnological investigation on respiration annual migratory cycle and other related phenomena in freshwater Pulmonate snails. Tans.Am.Microscope Soc., 53:348.

9. Chattopadhyay, G.N. (1998). Chemical analysis of fish pond soil and water. Daya Publishing House, Delhi.

10.Cruadrado, T.J.(2015). Preliminary assessment of freshwater Gastropods in the selected rivers in Esperanza, Agusan del Sur, Philippines. The Journal of Zoology Studies, 2(4):13-20.

11.De, A., Bose, R., Kumar, A., and Mozumder, S. (2014). Targeted delivery of pesticides using biodegradeable polymeric nano particles.Springer Briefs in Molecular Science, New Delhi, Springer India.https:// doi.org/10.1007/978-81-322-1689-6

12.Dutta,S.P.S., and Malhotra,Y.R .(1986). Seasonal variations in the macro-benthic fauna of Gadigarh stream(Miran Sahib) Jammu.Indian Journal of Ecology, 13,138-145.

13.Garg, R.K., Rao, R.J., and Saksena, D.N. (2009). Correlation of Molluscan diversity with physicochemical characteristics of water of Ramsagar reservoir. India. International Journal of Biodiversity and Conservation, 1: 202-207.

14.Gaufin, A.R. (1973). Use of Aquatic Invertebrates in the Assessment of Water Quality.Biological methods for the Assessment of water Quality.American Society for Testing Materials, 528: 96-116.

15.Hanaa, M.M., El-Khyat, Hoda Abdel-Hamid, Kadria, M.A.M., Hanan, S.G., Abu Taleb, M.A., and Hasan, E.F. (2016). Snails and fish as pollution biomarkers in lake Manzala and Laboratory C: Laboratory exposed snails to chemical mixtures. International Journal of Biological, Biomolecular, Agricultural, Food and Biotechnological Engineering, 10(11),719-730.

16. Heino, J. (2000). Lentic macro invertebrate assemblage structure along gradients in spatial heterogeneity, habitat size and water chemistry. Hydrobiologia, 418 229-242.

17. Hinrichsen, D., Robey, B. and Upadhyay, U.D. (1998). Solutions for a Water-Short World. Population Reports, Series M, No. 14.Baltimore, Johns Hopkins School of Public Health, Population Information Program, Baltimore, USA

18. Huet, M. (1986). Textbook of fish culture. Second edition, Fishing News Book Ltd., England.

19.Jhingran, V.G. (1982). Fish and fisheries of India.HidustanPublishers Corporation (India), Delhi.

20.Kamble, S.M.(2014). Water pollution and public health issues in Kohlapur City in Maharastra.International Journal of Scientific and Research Publications, 4(1),1-6.

21.Kumar, A. (1996). Comparative studies on diel variations of abiotic factors in lentic and lotic freshwater ecosystem of Santhal Parganas (Bihar). India Journal of Environmental and Pollution, 3: 53-56.

22.Lokhande, R.S., Singare, P.U., and Pimple, D.S. (2011).Study on physico-chemical parameters of waste water effluents from Taloja industrial area of Mumbai, India. International Journal of Ecosystem, 1 (1): 1-9.

23.Maltchick, L., Rolon, A.S., and Stenert, C. (2010).Aquatic macrophyte and macro invertebrate diversity and conservation in wetlands of the Sinos River Basin. Brazilian J.Biol, 70:1179-1184.

24.Modak, D.M., Singh, K.P., Ahmed, S., and Ray, P.K. (1990). Trace metal ion in Ganga water system. Chemosphere, 21(1-2): 275-287.

25.Palanisamy, S., and Khan, A.B(2012). Influence of Environmental Parameters on the Distribution and Diversity of Molluscan Composition in Pondicherry Mangroves, South Coast of India. Ocean Science Journal, 47(1):61-71.

26.Pawari, M.J., and Gawande, S.(2015).Ground water pollution and its consequence. International Journal of Engineering Research and General Science .3 (4),773-776.

27.Patil, D. (2009). A lot's fishy about our creek and lake fish. Dly. Times India, 22(33),4-5.

28.Pennak, R.W. (1978). Fresh-water Invertebrates of the United States (SecondEdition), John Wiley and Sons, New Yark, pp 803.

29.Roy, M., Nandi, N., and Banerjee, S. (2014). Macrozoobenthic community and Assessment of Aquatic Ecosystem Health of three waterbodies of East Kolkata etlands, India. Procedings of Zoological Society, 67(2): 86-93.

30.Saddozai, S., Baloch, W.A., Achakzai, W.M. and Memon, N. (2013). Population dynamics and ecology of freshwater Gastropods in Manchar lake, Sindh, Pakistan. The Journal of Animal and Plant Sciences, 23(4):'1089-1093

31.Selvanayagam, M., and Abril, R. (2016).Use of ben- 
thic macro invertebrates as a biological indicator in assessing water quality of river Puyo, Puyo, Pastaza, Eucador. American Journal of Life Sciences,4(1):112

32.Seyoum, E. (2007). Assessment of the physicochemical parameters of river Beressa in DebreBerhan town(North Shoa) for sustainability of drinking water, M.Sc thesis, School of Graduate Studies, Addis Ababa University.

33.Sharma, K.K., Bangotra, K., and Saini, M.(2013). Diversity and distribution of Mollusca on relation to the physico-chemical profile of Gho-Manhasan stream, Jammu(J\&K). International Journal of Biodiversity and Conservation, 5(4): 240-249. https:// doi.org/10.5897/IJBC12.127

34.Sharma,R.C (1986). Effect of Physico-chemical factors on benthic fauna of Bhagirathi river, Garhwal Himalayas. Indian Journal of Ecology,13:133-137.

35.Singh H.R., Badola, S.P., and Dobriyal, A.K.,( 1982). Ecology of the river Nayar of Garhwal Himalaya. Uttar Pradesh Journal of Zoology, 2: 72-76.

36.Smitha and Mustak MS (2017). Gastropod diversity with phusico-chemical characteristics of water and soil in selected areas of Dakshina Kannada district of Karnataka, India. International Journal of Fauna and Biological Studies, 4(1):15-21.

37.Strzlec, M., and Krolczyk, A (2004). Factors affecting snail community structure in upper course of the
Warta river(Poland).Biologica Bratislava.59(2):159.

38.Strzelec, M., Krodkiewska, M. and Krolczyk, A. (2014). The impact of environmental factors on the diversity of Gastropod communities in sinkhole ponds in a coal mining region (Silesian Upland, Southern Poland). Biologia, 69(6): 780-789.

39.Tonapi, G.T. (1980). Freshwater invertebrates of India (An ecological approach). IBH and Oxford Publication, New Delhi, India.

40.Wallace, J.B, and Webster, J.R,(1996). The role of macro invertebrate in stream ecosystem function. Annual Review of Entomology, 41: 115-139.

41.Ward, H.B. and Whipple, G.C. (1959).Freshwater Biology IIED.John Wiley and Sons. Inc., New Yark.

42.Welch, P.C. (1952). Limnology.Toronto and London. Mc. Graw Hill Book Co., NewYark. Wetzel, R.G. (1983) Recommendations for future research on periphyton: Wetzel, R.G (Ed), Periphyton of freshwater ecosystems.,pp.339-346.

43.WWAP (United Nations World Water Assessment Programme)/UN-Water. The United Nations World Water Development Report 2018: Nature Based Solutions for water(2018), Paris, UNESCO.

44.WWAP (United Nations World Water Assessment Programme) UN-Water. The United Nations World Water Development Report 2017: Wastewater: The Untapped Resources (2017), Paris, UNESCO. 